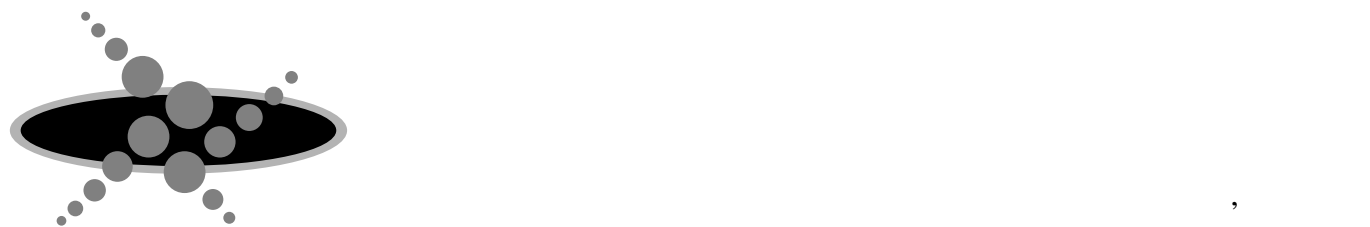

\begin{abstract}
Internal water molecules are considered to play a crucial role in the functional processes of ion pump proteins, though little has been known about their structure and function. We have studied hydrogen-bonding alterations of internal water molecules in a light-driven proton pump, bacteriorhodopsin, by means of low-temperature Fourier-transform infrared (FTIR) spectroscopy. Highly accurate measurements enabled us to detect even a single stretching vibration of such water molecules. In addition, analysis of the water molecules hydrating with negative charges led to a proposal of the "hydration switch model" for the primary proton transfer reaction in bacteriorhodopsin.
\end{abstract}

proton pump / retinal / hydrogen bond / Fourier-transform infrared spectroscopy / internal water molecule / isotope effect

\section{1.はじめに}

タンパク質は一般に疎水部を水から避ける形で折り 畳まれるが, 疎水的な内部に水分子が存在する場合も ある. これら内部結合水のなかには単に空間を充填す るだけでなく, 機能に重要な役割を演ずる水分子の存 在が考えられている.たとえば, タンパク質内部の電荷 対構造を安定化する水分子や, タンパク質内部でのイ オン輸送を補助する水分子が光れである. しかしなが ら, これらの内部結合水がタンパク質の機能発現過程 において具体的にどのような役割を担っているのか， 実験的に示された例は皆無である. タンパク質という 複雑系において, 個々の水分子の变化を実験的に捉え るのがいに困難かは容易に想像できるだろう.

内部結合水の役割を考えるとき, 特に興味深いのは 濃度勾配に逆らってイオンを輸送する分子ポンプタン パク質である. 能動輸送というエントロピーを減少さ せるポンプのはたらきに, 水分子はどのようにかかわ るのであろうか？ 2003 年のノーベル化学賞が示すと おり, 膜タンパク質は生命科学の重要な研究対象とな っているが, 分子ポンプ機構にかかわる水分子のはた らきにはほとんど手がつけられていない.このような 現状のもとで, 著者らはポンプタンパク質のトップラ ンナーであるバクテリオロドプシン (BR) を対象とし
て, 低温赤外分光を用いた研究を行っている11. 精度の 高い分光計測を実現することで, タンパク質内部に特 異的に結合した水分子 1 個の信号を抽出することに成 功し, 水分子の水素結合変化に関する新しい知見を得 てきた. 本稿では, きわめて強い水素結合を形成した水 分子の観測と光れをもとにしたプロトン移動機構を解 説することを目的として, 我々のBR研究を紹介したい，

\section{2.これまでのBRの研究}

\section{1 プロトン経路とスイッチ部位}

$\mathrm{BR}$ は高度好塩菌に存在する光駆動プロトンポンプ タンパク質である (Fig.1). 光を吸収するための発色団 としてレチナール分子をもち, 視物質ロドプシンと同 樣に 7 回膜貫通型構造をしている.レチナール発色団 はLys216とプロトン化したシッフ塩基結合を形成して いる. 光を吸収すると, $\mathrm{J}, \mathrm{K}, \mathrm{L}, \mathrm{M}, \mathrm{N}, \mathrm{O}$ と名付けられた 色の異なる中間体を経由する 10 ミリ秒程度の光反応サ イクルの間に, 細胞質側から細胞外側にプロトンを能 動輸送する ${ }^{1}$. 中性付近でのプロトン移動はFig.1の番 号で示した順番に起こる. まずM中間体の生成に伴っ て, (1)シッフ塩基から Asp85へのプロトンの移動が起 こると, (2) Glu204を中心とした放出基から細胞外側 ヘプロトンが放出される. 次にN中間体が生成する と, (3) Asp96からシッフ塩基へプロトンが移動する.

\title{
Vibrational Analysis of Internal Water Molecules in Bacteriorhodopsin
}

Mikihiro SHIBATA and Hideki KANDORI

Department of Materials Science and Engineering, Nagoya Institute of Technology 


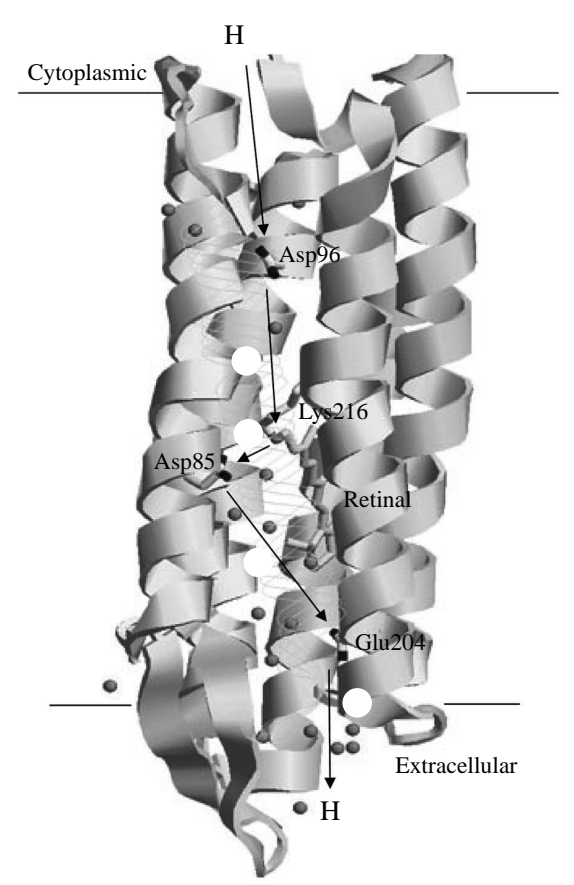

Fig.1 The proton pathway in $\mathrm{BR}$ ( crystal structure: PDB entry $\left.1 \mathrm{C} \mathrm{W}^{10)}\right)$. Important amino acids are highlighted with the retinal chromophore and bound water molecules. Proton translocation in BR is composed of 5 proton transfers, each of which accompanies formation and decay of intermediates.

O中間体の生成によって(4)細胞質側から Asp96にプロ トンが取り込まれる一方, O中間体から BRへ戻るとき に(5)Asp85から Glu204 にプロトンが移動する.

このようにBRのプロトンポンプは, タンパク質が時 間的・空間的に巧みに制御する 5 回のプロトン移動の 結果として実現するのであるが, 変異タンパク質を用 いた解析から, 方向性を決めるスイッチ部位がシッフ 塩基の領域に局在することが示唆された ${ }^{11}$. すなわち Asp96やGlu204 を変異させてこれらの部位をプロトン 経由地でなくしても, プロトンはポンプされたのであ る. 一方, Asp85 を変異させるとプロトンポンプ活性が なくなるばかりか, 条件によっては逆向きの塩素イオ ンポンプにもなり得る. このことは, シッフ塩基部位が 方向性を決めるスイッチとしてはたらくことを示唆し ている. 現在の共通理解としては, (1)のプロトン移動 に伴うタンパク質の構造変化が重要であり, 弚れによ って一方向性が生み出されるものと考えられている.

\section{2 内部結合水の重要性と炎の観測}

疎水的な膜内に電荷をもったプロトンを流すために は, 内部結合水が重要なはたらきをするものと考えら
れる. 実際にプロトン経路に水素結合を形成した水を 1次元的に配列すれば, 弚れ自身を運ぶことなく玉突き 的なメカニズムでプロトン輸送が可能である.このよ うなGrotthus タイプの移動機構はほかのイオンでは不 可能であり, 内部に水さえあれば効率のよい輸送が実 現できる(ただし, 完全につながっていると逆流してし まうが).

BRの内部結合水に対して実質的なメスを入れたの は京大の前田グループによる低温赤外分光法である21. もともとタンパク質の計測に赤外分光法は相性が悪い. 产れはタンパク質の環境である水分子が大きな赤外吸 収をもつので, タンパク質自身の信号がマスクされて しまうためである. このため, 高精度のフーリエ変換赤 外 (FTIR) 分光器が開発されても, 2 次構造をよく反映 した赤外線領域の豊かな振動情報は有効に活用されて いないのか現状であり,たとえばタンパク質のへリッ クス含量の算定には, 一般に紫外線領域の円二色性 (CD) 測定が用いられる. しかしながら, BRは (1) 水 和フィルム (乾燥フィルムを適度に湿らせたもの) で 正常な光反応を示すこと, (2) 光誘起の差スペクトル として変化成分だけを抽出することで詳細な構造変化 を解析できることから, 機能発現の過程で変化する水 分子を研究することが可能になった. 神取は前田グル ープの一員として, 観測された水分子がどこでどのよ うに変化するのかを,おもに変異タンパク質を駆使し て研究した. 光の結果, 1990 年代後半にかけて, BRのプ ロトン輸送経路に沿って数個の水分子が存在すること が明らかになった2),3).

次の大きなブレークスルーは1990年代後半に訪れ た. 高分解能X線結晶構造の登場である. Fig.1に示す $\mathrm{BR}$ の構造は, 10 個程度の内部結合水が偏りをもって存 在することを明らかにした (疎水的な細胞質側では少 なくなっている). BRに対するさらに大きな期待は, 結 晶中で光反応を起こさせることで, プロトン移動過程 のスナップショットを捉えることにあった. 実際に, 低 温での安定化や変異タンパク質を活用することで, わ ずか 5 年間のうちにKから $\mathrm{O}$ に至るすべての中間体構 造か報告されている. 兴れでは, 当初の期待どおり $\mathrm{BR}$ のプロトンポンプ機構は解明されたのだろうか? こ の問いに関しては, 残念ながら No と言わざるを得ない. なぜならば, 同一の中間体として同定された状態に対 し複数のグループが異なつた結晶構造モデルを提唱し ているからである.どれが正しい構造なのかわからず, かえって混乱を招いている.これにはさまざまな原因 が考えられるが, 最も重要なのはBR中でのわずかな構 造の違いが大きな機能の差につながる点である.たと 
えば,レチナールのわずかなねじれの違いによってシ ッフ塩基の N-H 基の方向は反対にもなるし, 水の位置 をわずかにずらすことで官能基のプロトン化状態は大 きく変わり得る. 光の意味では, 水素原子が見えないこ とも含め, 現在の分解能 (1.5 ̊程度) が十分でないこ とが本質的かもしれない. 混乱する中間体のX線結晶 構造解析の現状を報告することが本稿の目的ではない ので, これは将来の課題とだけ記しておきたい，

\section{3 . 赤外分光法の新たな進展}

\section{1 強い水素結合環境にある水分子の観測}

前述のとおり, プロトンの方向性を決める反応にとっ てシッフ塩基からAsp 85 へのプロトン移動が重要であ る. この反応が起こる領域は, タンパク質内部にもかか わらず2個の正電荷 (プロトン化シッフ塩基と Arg82) と負電荷 (Asp85 とAsp212) が電気四重極子を形成し, 兴れらを安定化するように 3 個の水分子が存在してい る (Fig.2). 水とアスパラギン酸の5 個の酸素原子は平 面的な五角形構造 (pentagon cluster) をとり, Asp 85 と Asp212が対称的に配置されているのが特徵である. 興味深いことに, シッフ塩基から 2 つのアス゚ラギン酸 へはほほ等距離であるにもかかわらず, ポンプの過程 でプロトンはAsp85に渡される.このような構造は同 じ古細菌ロドプシンファミリーである塩素イオンポン プのハロロドプシン (ただしAsp85か塩素イオンで置

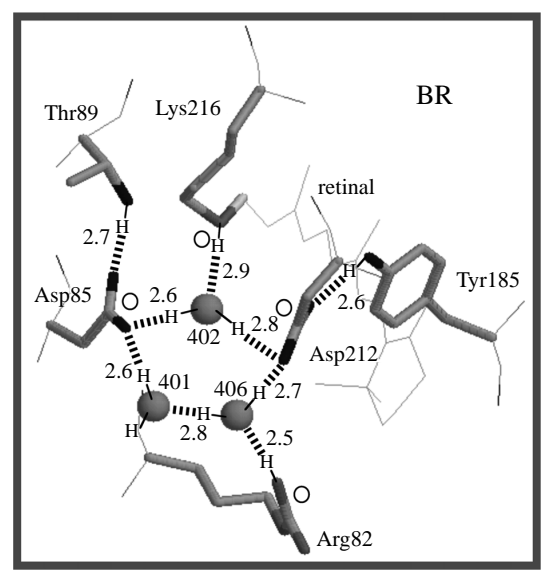

Fig.2 Crystal structure of the Schiff base region in BR ( $\mathrm{PDB}$ entry $\left.1 \mathrm{C} \mathrm{W}^{10}\right)$ ). The structure in this figure is approximately parallel to the membrane normal, and upper and lower regions correspond to the cytoplasmic and extracellular sides, respectively. Three water molecules ( 401, 402, and 406) and two oxygen atoms of aspartic acids ( Asp85 and Asp212) constitute a planar pentagonal cluster. Dotted lines represent supposed hydrogen bonds.
き換わっている) や光センサーのフォボロドプシンに

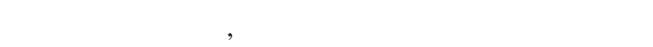
構造的基盤を提供するものであろう ${ }^{4)}$.

Fig.2のような構造を見たとき, 筆者の一人である神 取は赤外分光計測の新たな展開が必要であることを以 下のような理由て痛感した. 水分子は3700-3000 $\mathrm{cm}^{-1}$ の領域に $\mathrm{O}-\mathrm{H}$ 伸縮振動に由来する幅広い吸収をもち, 水素結合か強くなると低波数側に吸収か現れる. しか し, これまで赤外分光によって水の $\mathrm{O}-\mathrm{H}$ 伸縮を測定し てきたが, 測定上の制約から振動数は $3450 \mathrm{~cm}^{-1}$ より 高波数側に限られていた ${ }^{3)}$. すなわち, 水の振動として 実際に観測していたものは, 全体の $1 / 3$ 程度のほとんど 水素結合を形成していないO-H 伸縮振動であり,プロ トン移動に重要と考えられる水素結合を形成した水は 観測の対象ではなかった. しかしながら, シッフ塩基領 域での水は電荷対を橋渡ししたり, 負電荷に水和して いるため, 強い水素結合環境にあると考えられる. プロ トン移動という機能にかかわる水を捉えるためには,

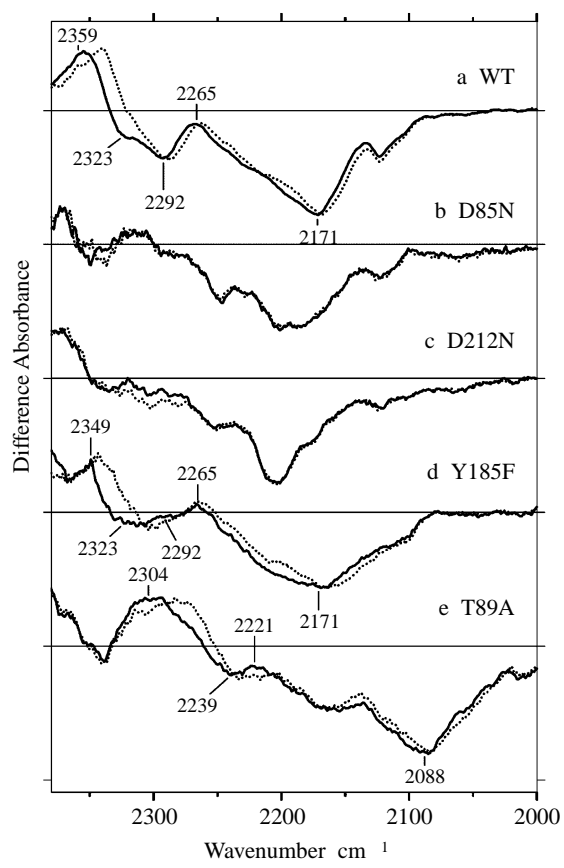

Fig.3 $\mathrm{K}$ minus $\mathrm{BR}$ difference infrared spectra of the wild type ( a), D85N ( b), D212N ( c), Y185F ( d), and T89A( e) BR in the $2380-2000 \mathrm{~cm}^{-1}$ region( modified from Ref.7). Solid and dotted curves represent measurements in $\mathrm{D}_{2} \mathrm{O}$ and $\mathrm{D}_{2}{ }^{18} \mathrm{O}$, respectively. These spectra were measured at $77 \mathrm{~K}$. One division of the $\mathrm{y}$ axis corresponds to 0.002 absorbance unit. Labeled frequencies correspond to these bands identified as water stretching vibrations. 
さらに低い振動数領域の水を実験的に捉える必要が あつた.

そこで神取は試料まで含めた測定系を最適化すると ともに, 重水中の測定で水素結合の強い水を捉えるこ とを試みた. BRは重水中では重水素をポンプするので, シッフ塩基領域の水は重水に置換されると考えられる. そこで重水素化されないタンパク質のX-H伸縮振動と 分離することによって, 水のO-D伸縮を $2700-2300 \mathrm{~cm}^{-1}$ の領域で観測することを期待した. Fig.3aにK中間体 との差スペクトルの一部を示すが, 予想どおり同位体 の水 $\left(\mathrm{D}_{2}{ }^{18} \mathrm{O}\right)$ でシフトする信号が水素結合の弱い 2700-2500 $\mathrm{cm}^{-1}$ だけでなく, <2400 $\mathrm{cm}^{-1}$ の領域にも 観測された5). 驚いたのは水のO-D 伸縮としてはきわめ て低い振動数である $2171 \mathrm{~cm}^{-1}$ に負のバンドか観測さ れたことである. このことはBR中できわめて強い水素 結合環境にある水の水素結合が, レチナールの異性化 反応によって弱くなることを示している. 神取らは 2000 年の論文中で, 負電荷に水和した水分子のO-D伸 縮振動と解釈した5). 実際, 同年に報告された林らの量 子化学計算に基づく基準振動計算によれば, ペンタゴ ンクラスター中で最も低い振動数は, water402がAsp85 と水素結合している方の伸縮振動に由来する ${ }^{6)}$.

3.2 変異タンパク質を用いた内部結合水の伸縮振 動の帰属

林らの計算によれば, 対称的に見えるwater402は実 際にはAsp85 と強い水素結合を形成し, もう一方のO$\mathrm{D}$ 伸縮は $350 \mathrm{~cm}^{-1}$ 以上高波数側に現れることになる6). つまり, Asp212 との相互作用はかなり弱いことになる. はたして, 量子化学計算が予想するとおり, 対称的に見 えるシッフ構造が実は非対称的な水和構造をしている のだろうか? 著者らはこの問題を実験的に解析する ことが重要であると考え, 以下の手順で変異タンパク 質を用いた解析を行った7).

林らの計算どおり, $2171 \mathrm{~cm}^{-1}$ の O-D伸縮振動が Asp85 と水素結合するwater402 に由来するのであれ ば, Asp85の電荷をなくすことで水素結合は弱くなる (=高波数側に現れる) が, Asp212の電荷をなくしても $2171 \mathrm{~cm}^{-1}$ のバンドはシフトしないと予想した. D $85 \mathrm{~N}$ 変異体を測定すると, 予想どおり $2171 \mathrm{~cm}^{-1}$ のバンドは 消失していた (Fig.3b). しかし予想に反して,D212N変 異体の場合も $2171 \mathrm{~cm}^{-1}$ の水分子由来のバンドはなく なってしまった (Fig.3c). (なお, D85NとD212Nに観 測される水に由来しない負のバンドは, 野生型にも現 れるシッフ塩基のN-D伸縮振動と考えられる ${ }^{8)}$.) Fig.3 でAsp85, Asp212の変異で2171 $\mathrm{cm}^{-1}$ のバンドばかり でなく, $2292 \mathrm{~cm}^{-1}$ と $2323 \mathrm{~cm}^{-1}$ のバンドも消失した
ことは, これらのバンドがペンタゴンクラスターを構 成している水分子 $(401,402,406)$ に由来することを 強く示唆するものである. しかしながら光の一方で, 最 も重要な $2171 \mathrm{~cm}^{-1}$ のバンドを帰属することはでき なかった. ペンタゴンクラスター内で負電荷をもつた アミノ酸の変異は, この領域の水素結合構造を大きく 変えてしまうのであろう.

そこでさらに2つの変異体を用いた. Asp85, Asp212 ではペンタゴンクラスターを構成しない酸素原子が 光れ光れThr89, Tyr185 と水素結合を形成している (Fig.1). 光こで変異によってこの水素結合を切ること で, アスパラギン酸側鎖の上の負電荷をペンタゴンク ラスター内の酸素原子に局在化させることを考えた. この場合も, 林の計算どおりであれば, $2171 \mathrm{~cm}^{-1}$ の水 分子のバンドにThr89の変異は影響するが, Tyr185の 変異は影響しないことが予想される. 実験の結果はこ

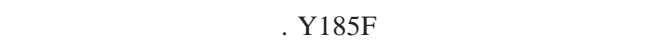
$2171 \mathrm{~cm}^{-1}$ のバンドが野生型と同じ振動数に現れたが (Fig.3d), T89Aでは2088 $\mathrm{cm}^{-1}$ に低波数シフトしたバ ンドが現れた (Fig.3e).

このような結果の最もストレートな解釈として,筆者 らは量子化学計算の結果と同樣, $2171 \mathrm{~cm}^{-1}$ の水のバン ドはwater402がAsp85に水和したO-D 伸縮に由来する と結論した7). プロトンドナーであるシッフ塩基とプロ トンアクセプターであるAsp85 を橋渡しする水分子が きわめて強い水素結合環境にあることは, BRの機能に とっても何らかの意味をもつものと考えられる. 実際 にこのような水をもつ $\mathrm{T} 89 \mathrm{~A} や \mathrm{Y} 185 \mathrm{~F}$ はプロトンポン プ機能があるのに対して, $2171 \mathrm{~cm}^{-1}$ 付近の水がない D85N と D212Nはプロトンをポンプできない.

\section{3 水和スイッチモデル}

シッフ塩基とAsp85 を橋渡しする $2171 \mathrm{~cm}^{-1}$ の水分 子は光のプロトン移動過程においてどのように変化す るのであろうか? これを明らかにするため, 谷本ら はK中間体だけでなく, 後期中間体における全波数 領域の水のO-D伸縮振動を測定した. 光の結果, 興味深 いことに水分子に由来する $2171 \mathrm{~cm}^{-1}$ の負のバンドは, プロトン移動前後のL, M中間体のいずれにおいても観 測されなかった ${ }^{91}$.このことは, water402がこれらの中 間体において, 負電荷に相当する強い水素結合のアクセ プターを見つけたことを示している. これらの結果を もとに, シッフ塩基から Asp85へのプロトン移動機構と して「水和スイッチモデル」が提唱された $(\text { Fig.4 })^{9)}$.

このモデルによると, Asp85 と water402 との強い相 互作用は, レチナールの異性化による $\mathrm{K}$ 中間体の生成 で弱まる.しかしながら, L中間体では光れが緩和して 


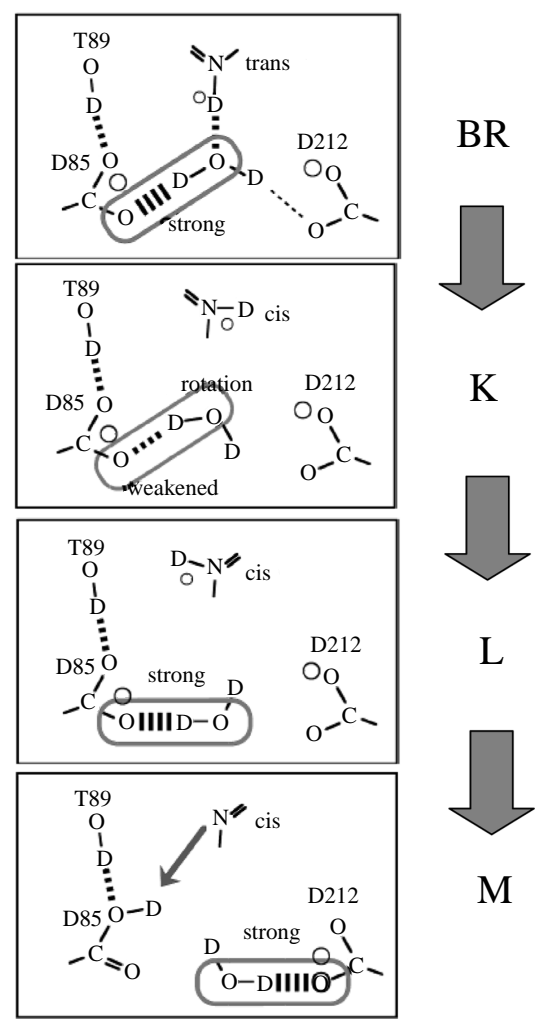

Fig.4 Hydration switch model as the proton transfer mechanism from the Schiff base to Asp85 ( modified from Ref. 9). Structure of the Schiff base region in $\mathrm{D}_{2} \mathrm{O}$ is schematically drawn. Strong hydrogen bond of water402, whose O-D stretch appears at $2171 \mathrm{~cm}^{-1}$, is highlighted in BR, L, and M. The acceptor is Asp85 in BR and L, while being switched to Asp212 in M. In this model, hydration switch of water402 from Asp85 to Asp212 is correlated with the proton transfer from the Schiff base to Asp85. The interaction of Thr89 and Asp85 is from our FTIR results ${ }^{11)}$.

もとの強い水素結合環境に戻った結果, 差スペクトル に負の $2171 \mathrm{~cm}^{-1}$ のバンドか観測されなかったものと 解釈できる. 後続する M中間体においても, $2171 \mathrm{~cm}^{-1}$ のバンドが現れなかったことから, BR と同樣にきわ めて強い水素結合環境の水分子が存在することがわ かる.ここで注目したいのは, BRからL中間体までは Asp85が負電荷をもつため, $2171 \mathrm{~cm}^{-1}$ の水の水素結合 アクセプターになると考えられるのに対して, M中間 体ではシッフ塩基からのプロトン移動によって Asp85 に負電荷が存在しないという点である. このとき, シッ フ塩基領域に存在する負電荷はAsp212だけである. 弚こでM中間体においては, water402 はAsp212 と強い 水素結合を形成すると考えた. 水和スイッチモデルではwater 402 がM中間体生成の 過程で水素結合の相手をAsp85から Asp212に変える 結果として, シッフ塩基のプロトンがAsp 85 に移動す る91. シッフ塩基領域で負電荷をもつた Asp212の役割 はこれまでよくわかっていなかったが, このような形 でのポンプへの関与が考えられる. このモデル自身は プロトンの平衡を 1 個の水か制御するというものであ りポンプの方向性を説明するものではないが, プロト ン移動後にシッフ塩基か細胞質側にアクセスを変える ことでポンプの一方向性が実現するものと考えられる. Grotthus タイプの玉突き的なプロトン移動機構は, BR においても疎水的な細胞質側で実現していると考えら れるが, 弚れだけではプロトン移動の方向性を説明で きない. このような特異なプロトン移動機構が, シッフ 塩基の向きを変える構造変化と共役して起こる結果, ベクトル性が現れるのであろう.

\section{4 . 結 論}

さまざまな工夫をすることで巨大な水和水の吸収を 克服して, 赤外分光によるBRの構造解析が実現した. 特に測定条件を最適化することにより, 水の大きな吸 収に隠されていたタンパク質の信号ばかりでなく, タ ンパク質に特異的に結合した水分子 1 個の水素結合変 化までも捉えることができた. 本稿て紹介したとおり， ポンプタンパク質のトップランナーであるBRの活性 中心に存在する内部結合水の振動解析は, BR の研究に 新たな進展をもたらした. しかしながら, ポンプ機構の 解明にはさらに詳細な構造変化の解析が必要であり, 光れを目指して今後も研究を続けたいと考えている.

\section{文 献}

1) 神取秀樹 (2001) 日本物理学会誌 56, 75-82.

2) Maeda, A. et al. (1997) J. Biochem. 121, 399-406.

3) Kandori, H. (2000)Biochim. Biophys. Acta 1460, 177-191.

4) Furutani, Y. and Kandori, H. (2002) Mol. Membr. Biol. 19, 257-265.

5) Kandori, H. and Shichida, Y. (2000) J. Am. Chem. Soc. 122, 11745-11746

6) Hayashi, S. and Ohmine, I. (2000) J Phys. Chem. B 104, 10678-10691.

7) Shibata, M. et al. (2003) J.Am. Chem. Soc. 125, 1331213313.

8) Kandori, H. et al. (2002) Biochemistry 41, 6026-6031.

9) Tanimoto, T. et al. (2003) Biochemistry 42, 2300-2306.

10) Luecke, H. et al. (1999) J. Mol. Biol. 291, 899-911.

11) Kandori, H. et al. (2001) Proc. Natl. Acad. Sci. USA 98, 1571-1576. 


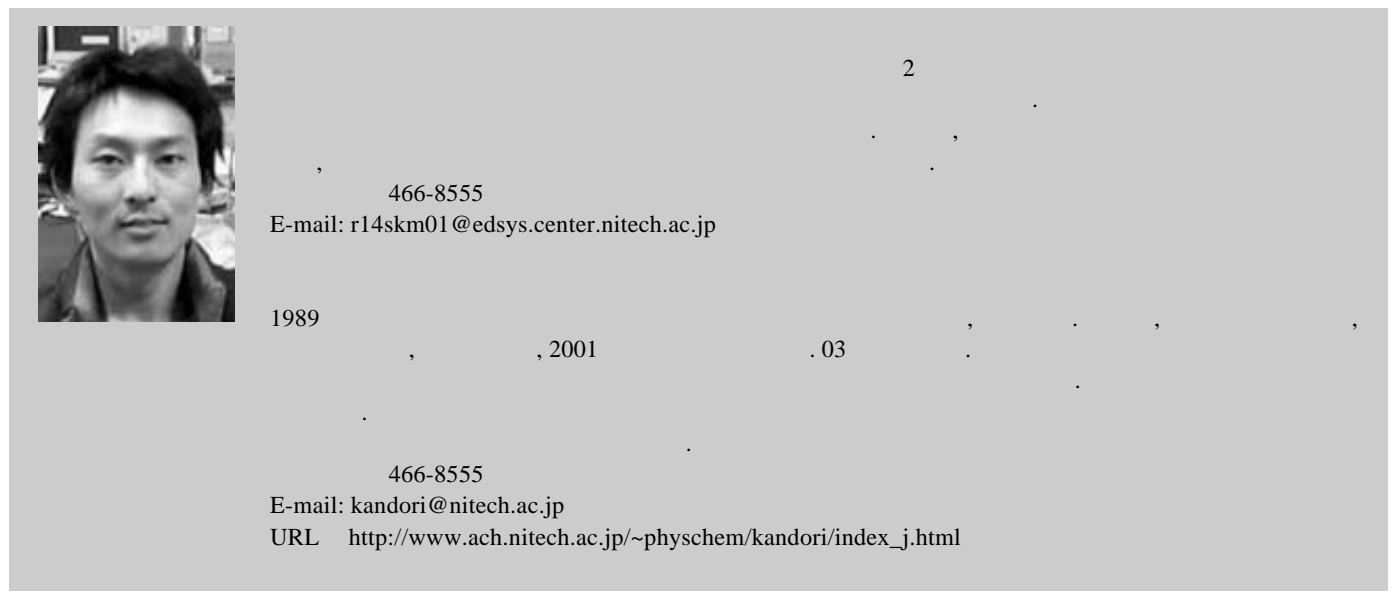

柴田幹大(しばた みきひろ)

名南市昭和区御器所田

京大での助手, 講師を経て, 2001 年より名工大助教授.03年より現職.

研究内容 : 光受容タンパク質におけるエネルギー変換・情報変換の機構解明.「○○でロドプシンをつく

る」こと.

E-mail: kandori@nitech.ac.jp

URL : http://www.ach.nitech.ac.jp/ physchem/kandori/index_j.html 